\title{
Isolation of antioxidant peptide from sandfish (Arctoscopus japonicus) roe hydrolysate
}

\author{
Hye Lim Jang ${ }^{1}$, Seung Ryeul Shin ${ }^{2}$, Kyung Young Yoon ${ }^{1 *}$ \\ ${ }^{1}$ Department of Food and Nutrition, Yeungnam University, Gyeongsan 38541, Korea \\ ${ }^{2}$ Faculty of Herbal Cuisine and Nutrition, Daegu Haany University, Gyeongsan 38578, Korea
}

\begin{abstract}
In this study, a peptide exhibiting antioxidant activity was isolated from sandfish (Arctoscopus japonicus) roe hydrolysate (SRH) in order to evaluate their practical uses as materials for manufacturing functional foods. The A. japonicus roe protein was hydrolyzed using Collupulin MG, and isolation of antioxidant peptide was performed using ultrafiltration (UF), prep-HPLC, and RP-HPLC. The SRH with a molecular weight below 3 kDa constituted about $38 \%$ of the whole hydrolysate, and the fraction with a molecular weight below $3 \mathrm{kDa}$ showed significantly greater antioxidant activity compared to the original SRH and other fractions. The isolation fold of the antioxidant peptide isolated from SRH throughout the four-step procedure was 7.11-fold, and protein yield was $14.8 \%$. The DPPH radical scavenging activity of isolated antioxidant peptide was above $90 \%$ at a concentration of $1.0 \mathrm{mg} / \mathrm{mL}$, which was similar to that of the Trolox at a concentration of $0.1 \mathrm{mg} / \mathrm{mL}$. These results suggested that the antioxidant peptide derived from $A$. japonicus roe could be a useful additive for producing functional foods and protein supplements. However, it is necessary to perform further study the structural characteristics of this antioxidant peptide isolated from A. japonicus roe.
\end{abstract}

Key words : sandfish, Arctoscopus japonicus, hydrolysate, isolation, antioxidant peptide

\section{Introduction}

Marine organism-derived bioactive peptides have been obtained by enzymatic hydrolysis of marine proteins. These peptides have many biological functions such as antihypertensive (1), anti-cancer (2), anti-microbial (3), antioxidant (4), and anti-inflammatory (5) activities. Bioactive peptides are usually composed of 3-20 amino acid residues, and their various activities are dependent on amino acid composition and sequence (6).

Oxidative stress caused by lipid oxidation contributes to the development and progression of diseases such as diabetes mellitus, neurodegenerative, cancer, and inflammatory diseases (7). In addition, lipid oxidation in foods causes flavor and texture alterations as well as nutrition loss, leading to

*Corresponding author. E-mail : yoonky2441@ynu.ac.kr Phone : 82-53-810-2878, Fax : 82-53-810-3746

Received 30 May 2017; Revised 18 July 2017; Accepted 18 July 2017.

Copyright (c) The Korean Society of Food Preservation. All rights reserved. shortened shelf-life of food products (8). Accordingly, many synthetic antioxidants such as propyl gallate (PG), butylated hydroxyanisole (BHA), and butylated hydroxytoluene (BHT) are widely used in the food industry to preserve food quality. However, use of large amounts of synthetic antioxidants causes stability problems in foods. Therefore, the identification of safe natural antioxidants to replace synthetic compounds is an important issue.

Many studies have already attempted the isolation and extraction of antioxidants (phenolic acid, flavonoids, carotenoids, and peptides) from natural materials such as grains, medicinal plants, vegetables, fruits, and fishes. Among others, antioxidant peptides isolated from products with abundant protein contents have been reported frequently in recent studies. For example, peptides isolated from protein hydrolysate of Pseudosciaena crocea was shown to exert antioxidant effects (9). Chi et al. $(10,11)$ reported three antioxidant peptides isolated from protein hydrolysate of bluefin leatherjacket skin and head, and Kangsanant et al. (12) investigated antioxidant peptides purified from Tilapia protein hydrolysate. Additionally, many researchers have 
identified antioxidant activity in peptides isolated from anchovy (13), sandfish (14), Mideodeok (15), chickpea (16), and bovine hair (17) protein hydrolysates. These results suggest that antioxidant peptides isolated from protein hydrolysates may be effectively used as food additives and pharmaceutical excipients (8).

Sandfish, Arctoscopus (A) japonicus, is a popular food in South Korea. It migrates to the East Sea in late autumn, spawning in shallow waters $(2-10 \mathrm{~m}$ in depth) in the winter (18). During this spawning season from November to December, many $A$ japonicus are captured and consumed (19). Catches of $A$ japonicus are on an increasing trend, with catches from 4,236 M/T in 2010 to $4,762 \mathrm{M} / \mathrm{T}$ in 2015 (20). In particular, $A$ japonicus is caught in large quantities in the East Sea of Korea, and, it is superabundant due to falling consumption. Therefore, it is necessary to utilize superabundant $A$ japonicus as a material for food processing. In addition, roe of $A$ japonicus is rich in protein, and its protein hydrolysate was able to inhibit lipid oxidation in a preliminary study. Nevertheless, there is insufficient information about bioactive peptide derived from $A$ japonicus roe protein hydrolysate. Thus, the present study was undertaken to isolate antioxidative peptide from $A$ japonicus roe and present the feasibility as materials for manufacturing functional foods and pharmaceutical products.

\section{Materials and Methods}

\section{Material}

Sandfish ( $A$ japonicus, $90 \pm 10 \mathrm{~g}$ in weight and $18.0 \pm 2.2$ $\mathrm{cm}$ in length) was purchased from a wholesale market located in Daegu, South Korea and transported on ice to the laboratory. The roe was separated from sandfish and grinded in a food mixer (M-1211, Starion, Busan, Korea). The temperature was maintained a constant during grinding in order to minimize the quality changes in roe, and the grinded samples were stored in a deep freezer (MDF-435, Sanyo, Tokyo, Japan) at $-40^{\circ} \mathrm{C}$.

\section{Preparation of sandfish roe hydrolysate (SRH)}

Before protein hydrolysis, roe of sandfish was defatted as followed by Klompong et al. (21) with some modifications. The grinded roe was stirred with isopropyl alcohol (Sigma Chemical, St. Louis, MO, USA) (1:4, w:v) for $50 \mathrm{~min}$ at room temperature. After centrifugation at $700 \times g$ for $30 \mathrm{~min}$, the supernatant was discarded, and the precipitate was collected and lyophilized using a freeze dryer (FD-1, Eyela, Tokyo, Japan) for 5 days.

Results of our preliminary antioxidant experiments using different commercial proteases (Alcalase $2.4 \mathrm{~L}$, Collupulin MG, Flavourzyme 500MG, Neutrase 0.8 L, and Protamex) (Novo Nordisk Co., Bagsvaerd, Denmark) showed that the antioxidant activity of the hydrolysate obtained using Collupulin MG was the highest among all hydrolysates. In addition, the results of our preliminary study indicated that the hydrolysate obtained using Collupulin MG recorded its highest antioxidant activity at $\mathrm{pH} 9.0$ with a hydrolysis temperature of $60^{\circ} \mathrm{C}$, enzyme/substrate ratio of $5 \%(\mathrm{w} / \mathrm{w})$, and hydrolysis time of $1 \mathrm{~h}$. Thus, the following hydrolysis conditions were used in the present study: defatted roe was mixed with distilled water at a ratio of 1:10 (w:v) and boiled at $90^{\circ} \mathrm{C}$ for $20 \mathrm{~min}$ to inactivate endogenous enzymes. The $\mathrm{pH}$ of the mixture was adjusted to 9.0, and enzyme was added to the reaction mixture at a final activity of $1,150 \mathrm{U}$ (enzyme/substrate ratio of $5 \%$ ). The solution was incubated at $60^{\circ} \mathrm{C}$ for $1 \mathrm{~h}$ and then boiled at $90^{\circ} \mathrm{C}$ for $20 \mathrm{~min}$ to inactivate the enzyme. Next, the mixture was centrifuged at $1,600 \times g$ for $30 \mathrm{~min}$ to isolate the hydrolysate. The hydrolyzed supernatant was collected, lyophilized for 5 days, and stored at $-40^{\circ} \mathrm{C}$ for future analysis.

\section{Measurement of degree of hydrolysis ( $\mathrm{DH})$}

The Measurement of DH was followed by Sathivel et al. (22) with a slight modification. The SRH was mixed with an equal amount of $20 \%$ trichloroacetic acid (TCA) (Sigma Chemical) to obtain $10 \%$ TCA-soluble protein, followed by centrifugation at $1,600 \times g$ for $30 \mathrm{~min}$. TCA-soluble protein in the supernatant was analyzed using the bicinchoninic acid (Sigma Chemical) method (23) with bovine serum albumin (Sigma Chemical) as the standard. The DH was calculated as follows:

$\% \mathrm{DH}=(10 \% \mathrm{TCA}-$ soluble protein/Total protein $) \times 100$

\section{Measurement of antioxidant activity}

In the preliminary study, the highest DPPH radical scavenging activity was observed in crude hydrolysate, relatively to ABTS radical scavenging activity, hydroxyl radical scavenging activity, nitrite scavenging activity, and metal chelating activity. Therefore, DPPH radical scavenging activity was selected to estimate antioxidant activity of the fractions. DPPH radical scavenging activity was measured according to the method described by Jang et al. (14) with 
slight modifications. Sample $(1 \mathrm{~mL})$ was added to $0.5 \mathrm{~mL}$ of $0.2 \mathrm{mM}$ 1,1-diphenyl-2-picryl hydrazyl (DPPH, Sigma Chemical). The mixture was shaken for $5 \mathrm{sec}$ and incubated in a water bath at $37^{\circ} \mathrm{C}$ for $30 \mathrm{~min}$. Absorbance was then measured at $517 \mathrm{~nm}$ with a spectrophotometer (U-2900, Hitachi Ltd., Tokyo, Japan). Radical scavenging activity was calculated as follows:

\% DPPH radical scavenging activity $=\left[\left(\mathrm{A}_{\text {control }}-\mathrm{A}_{\text {sample }}\right) /\right.$ $\left.A_{\text {control }}\right] \times 100$

where $A_{\text {control }}$ is the absorbance of the control (blank) and $\mathrm{A}_{\text {sample }}$ is the absorbance of the hydrolysate.

\section{Ultrafiltration (UF)}

To isolate antioxidant peptides from the SRH, the SRH was fractionated using an UF system with molecular weight cut-off (MWCO) values of 3, 5, and $10 \mathrm{kDa}$. The SRH fraction was divided into four parts designated as $>10 \mathrm{kDa}, 5-10$ $\mathrm{kDa}, 3-5 \mathrm{kDa}$, and $<3 \mathrm{kDa}$. All fractions were lyophilized and their molecular weight distribution and antioxidant activity evaluated. The degree of molecular weight distribution was expressed as the relative percentage of each yield.

Preparative high performance liquid chromatography (prep-HPLC)

The fraction with the highest antioxidant activity was separated on a XBridge PST $\mathrm{C}_{18}$ preparative column $(10 \mathrm{~mm} \times$ $250 \mathrm{~mm}$, Waters Co., Milford, MA, USA) connected to an HPLC system (Waters 2695, Waters Co.). The solvents used were $0.1 \%(\mathrm{v} / \mathrm{v})$ trifluoroacetic acid (TFA) (Sigma Chemical) in distilled water (solvent A) and $0.1 \%$ (v/v) TFA in $80 \%$ acetonitrile (solvent B). The flow rate was $5.0 \mathrm{~mL} / \mathrm{min}$ with a linear gradient of $0-50 \%$ solvent $\mathrm{B}$ in $30 \mathrm{~min}$. The loaded fraction was divided into six fractions by an automatic Foxy Jr. fraction collector (Teledyne Isco, Lincoln, NE, USA). The activity of each fraction was measured using DPPH radical scavenging activity assay. The fraction exhibiting the strongest antioxidant activity was pooled and lyophilized.

Reverse-phase high performance liquid chromatography (RP-HPLC)

The fraction collected by prep-HPLC was loaded onto an Atlantis ${ }^{\mathrm{TM}} \mathrm{dC}_{18}$ column $(4.6 \mathrm{~mm} \times 150 \mathrm{~mm}$, Waters Co. $)$ connected to a HPLC system (Waters Co.). The solvents used (solvent A and solvent B) were prepared as described above. The flow rate was $0.8 \mathrm{~mL} / \mathrm{min}$ with a linear gradient of
0-100\% solvent B in 15 min. DPPH radical scavenging activities of the loaded fractions were measured. The fraction exhibiting the highest antioxidant activity was pooled and lyophilized. The fraction was fractionated once again by RP-HPLC so only one peak was observed. The analytical conditions were the same as those already described. The isolated antioxidant peptide (IAP) used for all follow-up experiments was pooled and lyophilized.

\section{Statistical analysis}

Results of the study are presented as the mean and standard deviation (mean $\pm \mathrm{SD}$ ). All experiments were performed in triplicate. Collected data were subjected to analysis of variance (ANOVA), and Duncan's multiple range test was used to identify significant differences $(\mathrm{p}<0.05)$. All statistical analyses were carried out using SPSS ver. 21.0 software (SPSS Inc., Chicago, IL, USA).

\section{Results and Discussion}

\section{Degree of hydrolysis}

The DH of the hydrolysate affects processing of food products since functional properties such as protein solubility, emulsification, and foaming are susceptible to the DH. For instance, hydrolysate exhibiting high solubility can be easily mixed with other ingredients and displays superior wetting when stirred into liquids (14). Moreover, the DH influences the biological properties of peptides produced during hydrolysis due to its effects on amino acid composition as

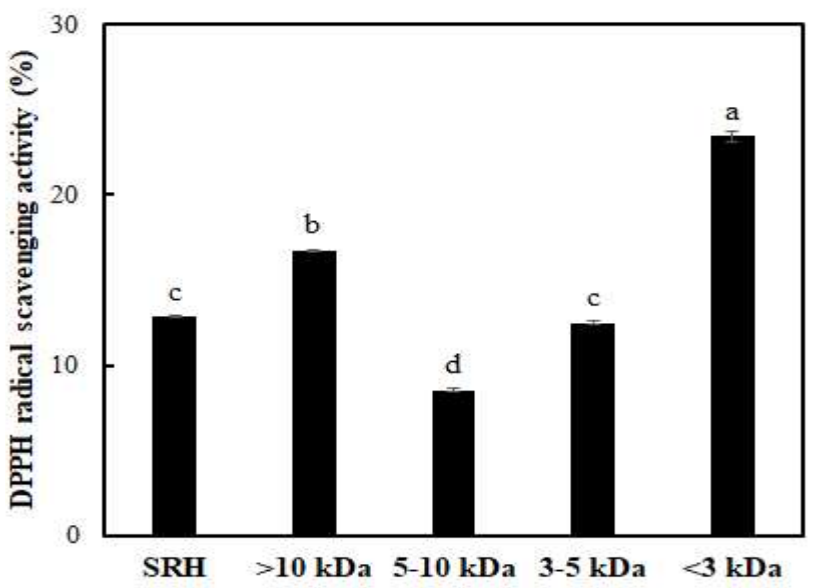

Fig. 1. DPPH radical scavenging activity of original sandfish roe hydrolysate (SRH) and fraction obtained by ultrafiltration.

DPPH radical scavenging activity was tested at a concentration of $1.0 \mathrm{mg} / \mathrm{mL}$. The results are expressed as the mean $\pm S D$ of triplicates. Values with different letters are significantly different $(\mathrm{p}<0.05)$. 
well as peptide size or structure $(21,24)$. In this study, the $\mathrm{DH}$ of the SRH under optimum hydrolysis conditions was $55.07 \%$ (data not shown). Similar observations were reported in another study. Ovissipour et al. (25) reported $\mathrm{DH}$ values of more than $53 \%$ for the protein hydrolysate obtained from yellowfin tuna visceral waste. In addition, Bhaskar et al. (26) and Bhaskar and Mahendrakar (27) reported that the $\mathrm{DH}$ of the protein hydrolysate obtained from Catla viscdral waste was close to $50 \%$. Souissi et al. (24) reported that hydrolysates with low DH values contain highly hydrophobic peptides, whereas hydrolysates with high $\mathrm{DH}$ values include highly hydrophilic peptides. Therefore, the results of the present study are expected to impact the various characteristics of peptides, which will be isolated later on.

\section{Isolation of antioxidant peptide from SRH}

Molecular weight is one of the most important factors affecting production of protein hydrolysates with expected functional properties for use as biomaterials (28). Accordingly, the degree of molecular weight distribution for the four fractions ( $>10 \mathrm{kDa}, 5-10 \mathrm{kDa}, 3-5 \mathrm{kDa}$, and $<3 \mathrm{kDa}$ ) was obtained by UF (Table 1), and the antioxidant activities of the different molecular weight fractions were determined (Fig. 1).

The SRH with a molecular weight below $3 \mathrm{kDa}$ constituted about $38 \%$ of the whole hydrolysate. This indicates that the SRH contained mostly low molecular weight peptides. Similar results were reported by You et al. (29) in a study on antioxidant peptide derived from loach (Misgurnus anguillicaudatus). The fraction with a molecular weight
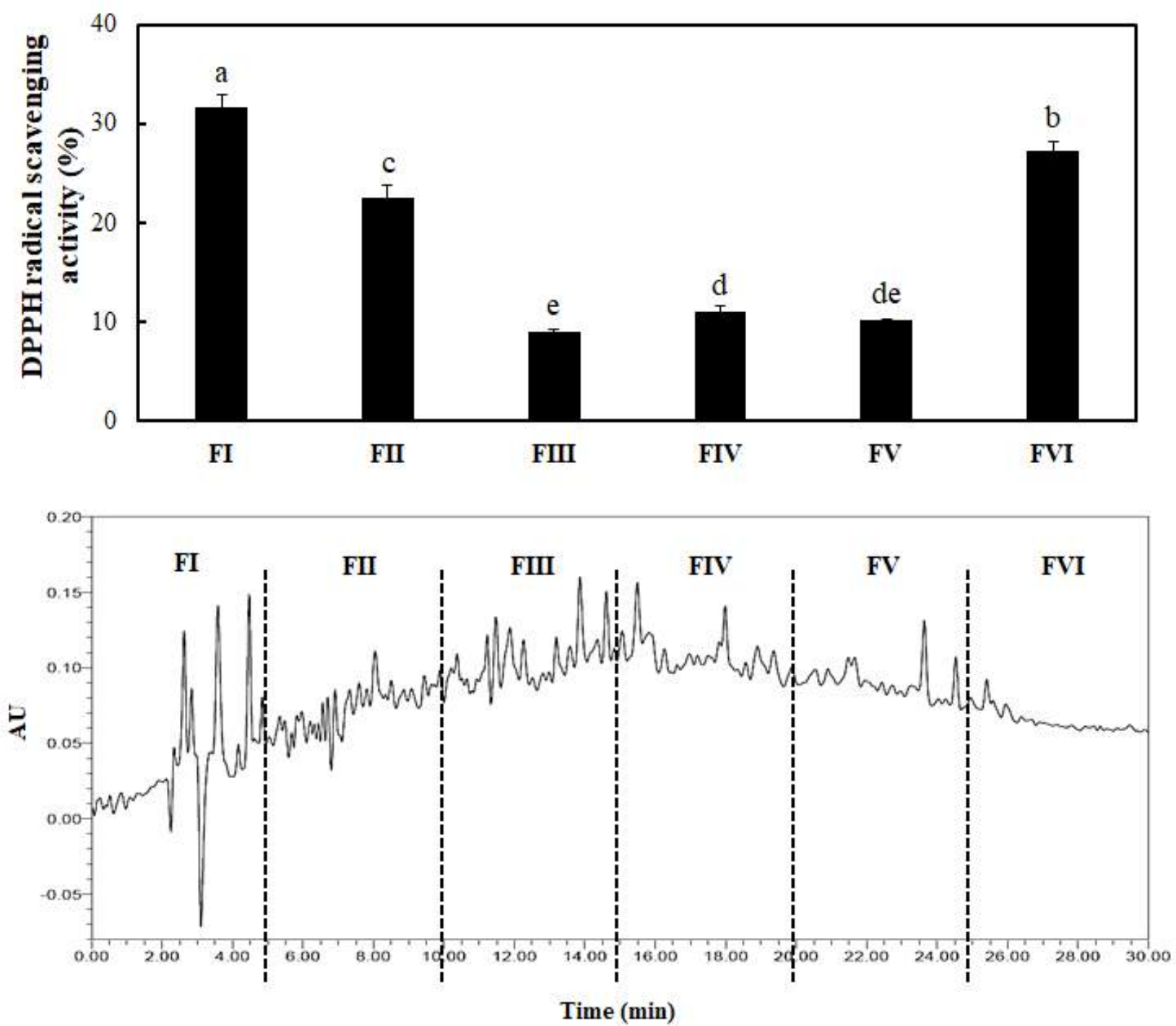

Fig. 2. Elution profile of SRH separated by prep-HPLC and DPPH radical scavenging activities of the separated fractions.

DPPH radical scavenging activities were measured at a concentration of $1.0 \mathrm{mg} / \mathrm{mL}$. Results are expressed as the mean $\pm \mathrm{SD}$ of triplicates. Values with different letters are significantly different $(\mathrm{p}<0.05)$. 
Table 1. Degree of molecular weight distribution for sandfish roe hydrolysate

\begin{tabular}{cc}
\hline \multirow{2}{*}{ Molecular weight } & Distribution (\%) \\
\cline { 2 - 2 } & $\mathrm{SRH}^{1)}$ \\
\hline$>10 \mathrm{kDa}$ & $25.75 \pm 1.85^{2) \mathrm{b3})}$ \\
$5-10 \mathrm{kDa}$ & $17.15 \pm 0.87^{\mathrm{c}}$ \\
$3-5 \mathrm{kDa}$ & $19.59 \pm 2.30^{\mathrm{c}}$ \\
$<3 \mathrm{kDa}$ & $37.51 \pm 1.29^{\mathrm{a}}$ \\
\hline
\end{tabular}

${ }^{1)}$ SRH, sandfish roe hydrolysate.

${ }^{2)}$ The results are expressed as the mean $\pm \mathrm{SD}$ of triplicates.

${ }^{3)}$ Values in the same column with different superscript letters are significantly different $(\mathrm{p}<0.05)$. fraction with a molecular weight above $10 \mathrm{kDa}$ was the second highest after the fraction with a molecular weight below 3 $\mathrm{kDa}$. You et al. (30) reported a peptide with a molecular weight less than $3 \mathrm{kDa}$ showing the strongest hydroxyl radical scavenging activity. Chi et al. (9-11) also identified a fraction with a molecular weight below $1 \mathrm{kDa}$, which is the smallest molecular weight, with the highest antioxidant activity. However, Kim et al. (31) demonstrated that free radical scavenging activities of the smallest molecular weight fraction were lower than those of the fraction with a molecular weight of 5-10 kDa. In addition, Zhou et al. (32) reported that
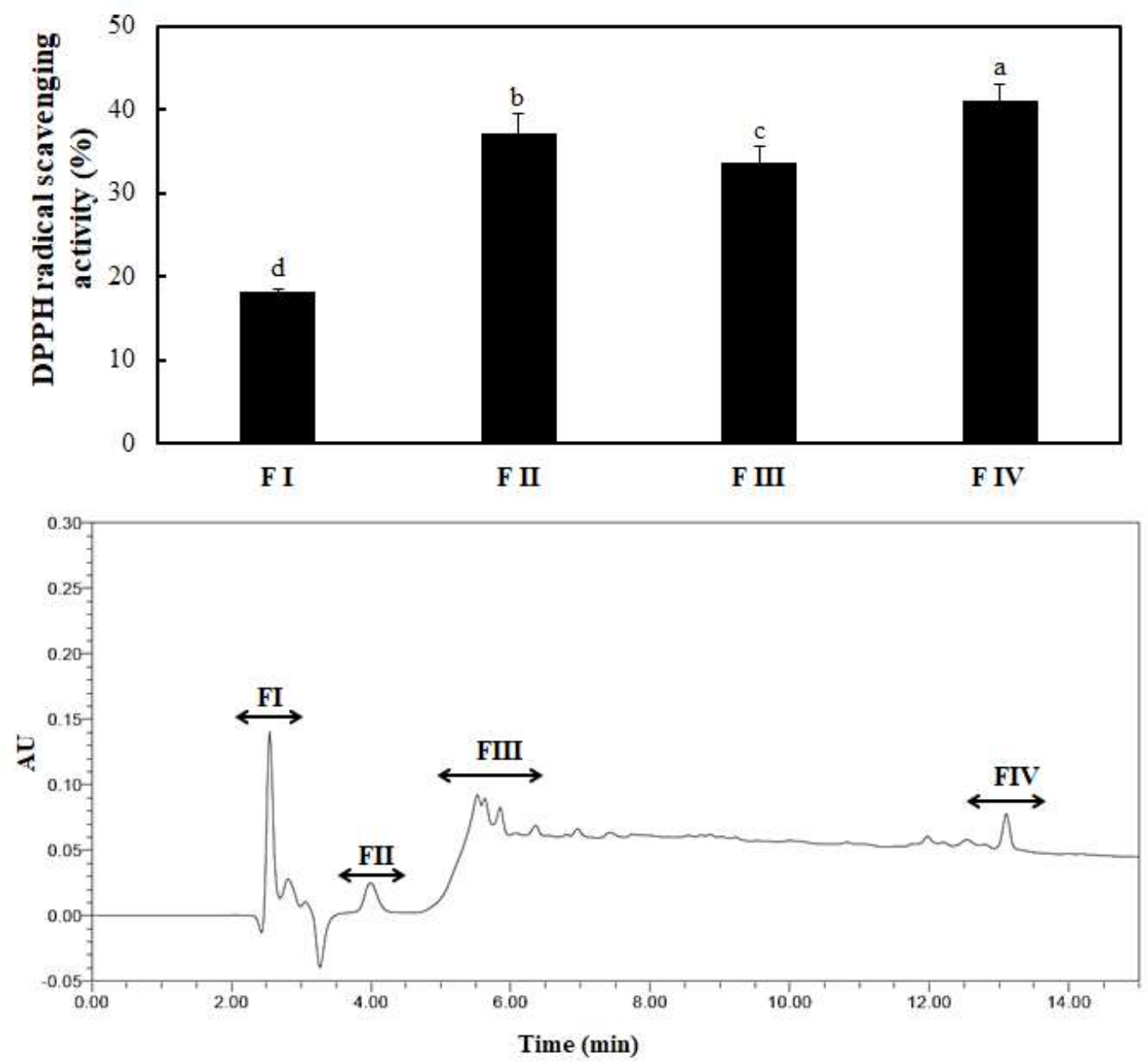

Fig. 3. Elution profile of SRH separated by the first round of RP-HPLC and the DPPH radical scavenging activities of the isolated fractions. DPPH radical scavenging activities were evaluated at a concentration of $1.0 \mathrm{mg} / \mathrm{mL}$. Results are expressed as the mean \pm SD of triplicates. Values with different letters are significantly different $(\mathrm{p}<0.05)$.

below $3 \mathrm{kDa}$ showed significantly greater antioxidant activity compared to the original SRH and other fractions. The antioxidant activity of SRH tended to increase with decreasing molecular weight, whereas the antioxidant activity of the a fraction with a molecular weight of 3-10 $\mathrm{kDa}$ more effectively scavenged DPPH radicals than a fraction with a molecular weight below $1 \mathrm{kDa}$. These results suggest that the antioxidant activity according to molecular weight differs 
by sample type. In the present study, the fraction with a molecular weight below $3 \mathrm{kDa}$, which showed the highest radical scavenging activity, was pooled and lyophilized for subsequent studies.

In Fig. 2, the column chromatographic profiles and DPPH radical scavenging activities are presented. A clear difference was observed between the fractions, and the scavenging activities of fractions I, II, III, IV, V, and VI were $31.72 \%$, $22.54 \%, 8.96 \%, 10.97 \%, 10.08 \%$, and $27.25 \%$, respectively. Briefly, fraction I exerted the strongest antioxidant activity among all fractions. Therefore, fraction I obtained by prep-HPLC was loaded onto a $\mathrm{dC}_{18}$ column for RP-HPLC and further divided into four major portions. The order of radical scavenging effects on the four fractions was $\mathrm{FI}<$ FIII < FII < FIV (Fig. 3). The DPPH radical scavenging activity of fraction IV was the highest (41.10\%) among all fractions. The fraction was continuously loaded again onto the same reverse-phase column and estimated under the same analytical conditions. Eventually, only a single peak was obtained, and a fraction with a DPPH radical scavenging activity of $91.25 \%$ was eluted (Fig. 4 and Table 2). The purification fold of the IAP from SRH throughout the four-step procedure was 7.11-fold, and protein yield was $14.8 \%$.

Table 2. Summary of isolation strategy for antioxidant peptide obtained from SRH

\begin{tabular}{lccc}
\hline \multicolumn{1}{c}{ Isolation step } & $\begin{array}{c}\text { DPPH radical scavenging } \\
\text { activity }(\%)^{1)}\end{array}$ & $\begin{array}{c}\text { Isolation } \\
\text { fold })^{2}\end{array}$ & $\begin{array}{c}\text { Protein yield } \\
(\%)^{3}\end{array}$ \\
\hline $\mathrm{SRH}^{4)}$ & 12.84 & 1.00 & 100.0 \\
Ultrafiltration $(<3 \mathrm{kDa})$ & 23.44 & 1.83 & 87.6 \\
Prep-HPLC (Fraction I) & 31.72 & 2.47 & 47.6 \\
$1^{\text {st }} \mathrm{RP}-\mathrm{HPLC}$ (FractionIV) & 41.10 & 3.20 & 15.9 \\
$2^{\text {nd }}$ RP-HPLC (Isolated peptide) & 91.25 & 7.11 & 14.8 \\
\hline
\end{tabular}

${ }^{1)} \mathrm{DPPH}$ radical scavenging activity was tested at a concentration of $1.0 \mathrm{mg} / \mathrm{mL}$.

${ }^{2}$ Isolation fold was calculated as a ratio of the radical scavenging activity of fraction obtained by each step relative to the radical scavenging activity of SRH.

${ }^{3}$ Protein yield was calculated as a percentage of the protein content of fraction obtained by each step relative to the protein content of SRH.

${ }^{4}$ SRH, sandfish roe hydrolysate.

\section{Antioxidant activity of IAP}

To evaluate the antioxidant activity of IAP, DPPH radical scavenging activities of IAP and various positive controls were compared (Fig. 5). IAP effectively scavenged the DPPH radical. The DPPH radical scavenging activity of IAP was above $90 \%$ at a concentration of $1.0 \mathrm{mg} / \mathrm{mL}$ which was similar to that of the Trolox at a concentration of $0.1 \mathrm{mg} / \mathrm{mL}$. Wang et al. (33) suggested that the DPPH method can be used for the primary characterization of the radical scavenging activity of bioactive compounds. In addition, Cheung et al. (34) reported that free radical scavenging such as DPPH radical scavenging is one of the well-known mechanisms caused through inhibition of lipid oxidation. Ranathunga et al. (35) indicated that high antioxidant activity induced by low molecular weight peptides may be caused by the ease of interaction between free radicals and low molecular weight peptides. Chen et al. (36) reported that antioxidant peptides with 5-16 amino acid residues could hinder the autoxidation of linoleic acid due to their remarkable ability to cross the intestinal wall and react more easily with free radicals. As a result, IAP showed potent the DPPH radical scavenging activity, which indicated that the IAP was good natural

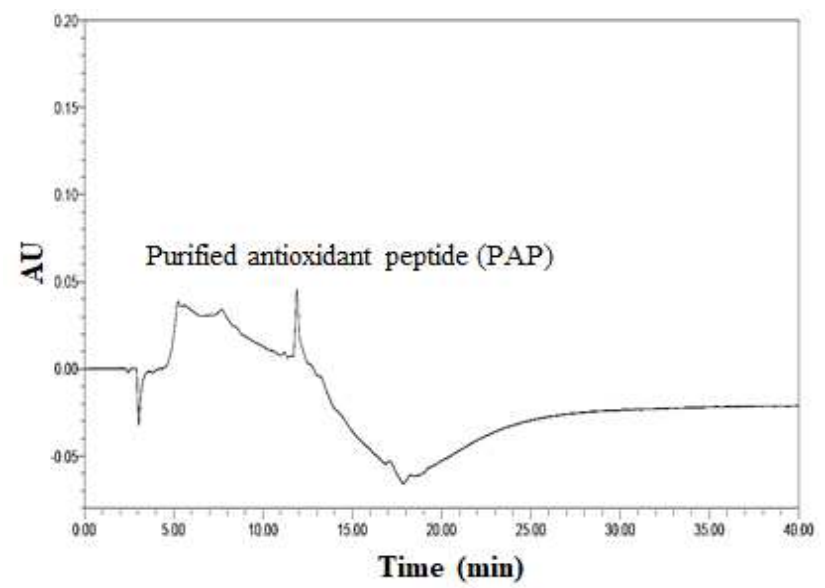

Fig. 4. Elution profile of SRH separated by the second round of RP-HPLC.

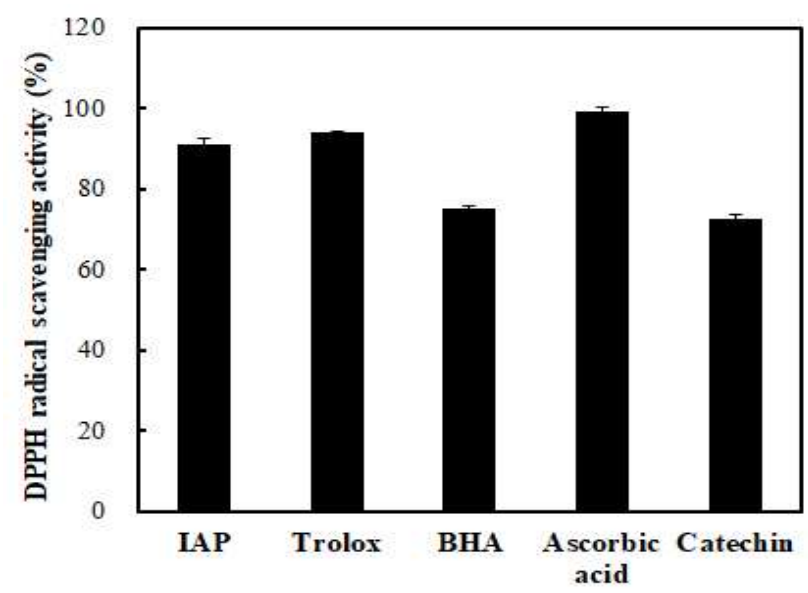

Fig. 5. DPPH radical scavenging activity of antioxidant peptide derived from $A$. japonicus.

IAP, isolated antioxidant peptide derived from $A$ japonicus roe.

DPPH radical scavenging activities of peptides were tested at a concentration of 1.0 $\mathrm{mg} / \mathrm{mL}$. DPPH radical scavenging activities of antioxidants were tested at a concentration of $0.1 \mathrm{mg} / \mathrm{mL}$. The results are expressed as mean $\pm S D$ of triplicates. 
antioxidant compounds for the anti-lipid peroxidation. Therefore, we suggest that it is possible to produce natural antioxidants from $A$ japonicus roe proteins. However, it is necessary to do further study the structural characteristics of antioxidant peptide isolated from $A$ japonicus roe.

\section{References}

1. Lee JK, Jeon JK, Byun HG (2011) Effect of angiotensin I converting enzyme inhibitory peptide purified from skate skin hydrolysate. Food Chem, 125, 495-499

2. Sheih IC, Fang TJ, Wu TK, Lin PH (2010) Anticancer and antioxidant activities of the peptide fraction from algae protein waste. J Agric Food Chem, 58, 1202-1207

3. Liu Z, Dong S, Xu J, Zeng M, Song H, Zhao Y (2008) Production of cysteine-rich antimicrobial peptide by digestion of oyster (Crassostrea gigas) with alcalase and bromelin. Food Control, 19, 231-235

4. Mendis E, Rajapakse N, Kim SK (2005) Antioxidant properties of a radical-scavenging peptide purified from enzymatically prepared fish skin gelatin hydrolysate. J Agric Food Chem, 53, 581-587

5. Duarte J, Vinderola G, Ritz B, Perdigon G, Matar C (2006) Immunomodulating capacity of commercial fish protein hydrolysate for diet supplementation. Immunobiology, 211, 341-350

6. Pihlanto-Leppala A (2000) Bioactive peptides derived from bovine whey proteins: opioid and ace-inhibitory peptides. Trends Food Sci Technol, 11, 347-356

7. Intarasirisawat $\mathrm{R}$, Benjakul $\mathrm{S}, \mathrm{Wu} \mathrm{J}$, Visessanguan $\mathrm{W}$ (2013) Isolation of antioxidative and ACE inhibitory peptides from protein hydrolysate of skipjack (Katsuwana pelamis) roe. J Funct Foods, 5, 1854-1862

8. Kumar NSS, Nazeer RA, Jaiganesh R (2012) Purification and identification of antioxidant peptides from the skin protein hydrolysate of two marine fishes, horse mackerel (Magalaspis cordyla) and croaker (Otolithes ruber). Amino Acids, 42, 1641-1649

9. Chi CF, Hu FY, Wang B, Ren XJ, Deng SG, Wu CW (2015) Purification and characterization of three antioxidant peptides from protein hydrolyzate of croceine croaker (Pseudosciaena crocea) muscle. Food Chem, 168, 662-667

10. Chi CF, Wang B, Hu FY, Wang YM, Zhang B, Deng SG, Wu CW (2015) Purification and identification of three novel antioxidant peptides from protein hydrolysate of bluefin leatherjacket (Navodon septentrionalis) skin. Food Res Int, 73, 124-129

11. Chi CF, Wang B, Wang YM, Zhang B, Deng SG (2015) Isolation and characterization of three antioxidant peptides from protein hydrolysate of bluefin leatherjacket (Navodon septentrionalis) heads. J Funct Foods, 12, 1-10

12. Kangsanant $S$, Thongraung C, Jansakul C, Murkovic M, Seechamnanturakit V (2015) Purification and characterisation of antioxidant and nitric oxide inhibitory peptides from Tilapia (Oreochromis niloticus) protein hydrolysate. Int J Food Sci Technol, 50, 660-665

13. Song R, Wei RB, Ruan GQ, Luo HY (2015) Isolation and identification of antioxidative peptides from peptic hydrolysates of half-fin anchovy (Setipinna taty). LWT-Food Sci Technol, 60, 221-229

14. Jang HL, Liceaga AM, Yoon KY (2016) Purification, characterisation and stability of an antioxidant peptide derived from sandfish (Arctoscopus japonicus) protein hydrolysates. J Funct Foods, 20, 433-442

15. Kang N, Ko SC, Samarakoon K, Kim EA, Kang MC, Lee SC, Kim J, Kim YT, Kim JS, Kim H, Jeon YJ (2013) Purification of antioxidative peptide from peptic hydrolysates of Mideodeok (Styela clava) flesh tissue. Food Sci Biotechnol, 22, 541-547

16. Kou X, Gao J, Xue Z, Zhang Z, Wang H, Wang X (2013) Purification and identification of antioxidant peptides from chickpea (Cicer arietinum L.) albumin hydrolysates. LWT-Food Sci Technol, 50, 591-598

17. Zeng WC, Zhang WH, He Q, Shi B (2015) Purification and characterization of a novel antioxidant peptide from bovine hair hydrolysates. Process Biochem, 50, 948-954

18. Chyung M (1977) The Fishes of Korea. Il Ji Sa, Seoul, Korea, p 727

19. Choi SH, Chun YY, Son SJ, Suh HK (1983) Age, growth and maturity of sandfish, Arctoscopus japonicus (Steindachner) in the eastern sea of Korea. Bull Nat Fish Res Dev Agency, 31, 7-19

20. Statistics Korea. Index of agriculture, forestry and fishing production. http://kosis.kr/statHtml/statHtml.do?orgId= 101\&tblId=DT_1EW0005\&vw_cd= (accessed May 2017)

21. Klompong V, Benjakul S, Kantachote D, Shahidi F (2007) Antioxidative activity and functional properties of protein hydrolysate of yellow stripe trevally (Selaroides leptolepis) as influenced by the degree of hydrolysis and enzyme type. Food Chem, 102, 1317-1327

22. Sathivel S, Smiley S, Prinyawiwatkul W, Bechtel PJ (2005) Functional and nutritional properties of red salmon 
(Oncorhynchus nerka) enzymatic hydrolysates. J Food Sci, 70, c401-c406

23. Smith PK, Krohn RI, Hermanson GT, Mallia AK, Gartner FH, Provenzano MD, Fujimoto EK, Goeke NM, Olson BJ, Klenk DC (1985) Measurement of protein using bicinchoninic acid. Anal Biochem, 150, 76-85

24. Souissi N, Bougatef A, Triki-Ellouz Y, Nasri M (2007) Biochemical and functional properties of sardinella (Sardinella aurita) by-product hydrolysates. Food Technol Biotechnol, 45, 187-194

25. Ovissipour M, Kenari AA, Motamedzadegan A, Nazari RM (2012) Optimization of enzymatic hydrolysis of visceral waste proteins of yellowfin tuna (Thunnus albacares). Food Bioprocess Technol, 5, 696-705

26. Bhaskar N, Benila T, Radha C, Lalitha RG (2008) Optimization of enzymatic hydrolysis of visceral waste proteins of Catla (Catla catla) for preparing protein hydrolysate using a commercial protease. Bioresour Technol, 99, 335-343

27. Bhaskar N, Mahendrakar NS (2008) Protein hydrolysate from visceral waste proteins of Catla (Catla catla): Optimization of hydrolysis conditions for a commercial neutral protease. Bioresour Technol, 99, 4105-4111

28. Deeslie WD, Cheryan M (1992) Fractionation of soy protein hydrolysates using ultrafiltration membranes. J Food Sci, 57, 411-413

29. You L, Zhao M, Regenstein JM, Ren J (2010) Purification and identification of antioxidative peptides from loach (Misgurnus anguillicaudatus) protein hydrolysate by consecutive chromatography and electrospray ionizationmass spectrometry. Food Res Int, 43, 1167-1173

30. You L, Zhao M, Liu RH, Regenstein JM (2011) Antioxidant and antiproliferative activities of loach (Misgurnus anguillicaudatus) peptides prepared by papain digestion. J Agric Food Chem, 59, 7948-7953

31. Kim SY, Je JY, Kim SK (2007) Purification and characterization of antioxidant peptide from hoki (Johnius belengerii) frame protein by gastrointestinal digestion. J Nutr Biochem, 18, 31-38

32. Zhou K, Sun S, Canning C (2012) Production and functional characterisation of antioxidative hydrolysates from corn protein via enzymatic hydrolysis and ultrafiltration. Food Chem, 135, 1192-1197

33. Wang JS, Zhao MM, Zhao QZ, Jiang YM (2007) Antioxidant properties of papain hydrolysates of wheat gluten in different oxidation systems. Food Chem, 101, 1658-1663

34. Cheung LM, Cheung PCK, Ooi VEC (2003) Antioxidant activity and total phenolics of edible mushroom extracts. Food Chem, 81, 249-255

35. Ranathunga S, Rajapakse N, Kim SK (2006) Purification and characterization of antioxidative peptide derived from muscle of conger eel (Conger myriaster). Eur Food Res Technol, 222, 310-315

36. Chen HM, Muramoto K, Yamauchi F, Nokihara K (1996) Antioxidant activity of designed peptides based on the antioxidative peptide isolated from digests of a soybean protein. J Agric Food Chem, 44, 2619-2623 